\title{
The Serology of Pseudomonas pyocyanea
}

\author{
BY ANNA MAYR-HARTING \\ Department of Preventive Medicine, University of Bristol
}

\begin{abstract}
SUMMARY: Three main antigens were found to be variously distributed amongst strains of Pseudomonas pyocyanea. The serological behaviour of the strains studied depended on the presence and quantity of these antigens. It was not possible to distinguish between flagellar and somatic antigens, but those found were probably somatic.

Amongst the peculiarities of serological behaviour of bacteria in this species the most striking was a complete loss of agglutinability on moderate heating, which left the antigenic activity unimpaired.
\end{abstract}

The classification of the genus Pseudomonas is, like most bacteriological classifications, one of contradictions. The species $P$ s. pyocyanea is not clearly delimited and most observers have found strains which, though most conveniently placed in that species, had one or more atypical characteristics. Within the species, classification has been attempted, but without conspicuous success. Gessard (1919, 1920), who made the first extensive study of the organism, based his classification entirely on pigment production. On this basis he not only determined whether a strain should be included in the species, but divided it into three varieties, each again subdivided into four 'races'. The validity of this classification depends on the assumption that pigment production is a constant property of strains; and ordinary laboratory experience does not support that assumption.

Aoki (1926) attempted a classification on the basis of cultural and serological characteristics. He found great variations in the association of different cultural characteristics, and treated $P$ s. pyocyanea, $P$ s. fluorescens and $P$ s. putida as one species, since a large number of strains could not be placed definitely in one or the other of these three previously described species. He found 22 serological types among 50 strains, and here again a clear division into three species was not possible. From his tables, however, it appears that each serological group contained only such strains as did not differ in pigment production. Sandiford (1937) tested 50 strains and also concluded that no cultural or serological distinction between Ps. pyocyanea and Ps. fuorescens was possible. Trommsdorff (1916) similarly investigated organisms of all three species and found that the results of cultural and serological classification did not coincide. By agglutination he could divide 25 out of 27 pyocyanea strains into three groups. He obtained cross-agglutination reactions between the three species, but concluded on the basis of absorption experiments that the three species were not antigenically identical.

Knowledge of bacterial dissociation has had few repercussions in the $\boldsymbol{P}$ seudomonas group, and it is still doubtful whether an $S \rightarrow R$ variation occurs. Recently Gaby (1946) described three basic colony variants that were present in each of 12 strains of $P s$. pyocyanea. These variants were not stable, each 
giving rise on subculture to the other variants. In 10 of the 12 strains the three variants were serologically different, and the analogous variants of various strains serologically identical. The remaining two were not agglutinated by any of Gaby's type sera. It is probable, therefore, that Gaby investigated the variants of one serological group only. The serological differences between the variants Gaby assumes to be due to differences in flagellar antigens, whereas the somatic antigens are identical. This conclusion is based on the agglutination results with formalin- and ethanol-treated suspensions. From his tables it is apparent that the differences between the agglutination of formalin-treated suspensions of the three variants are clearcut and his conclusions as to the identity of the corresponding variants in all strains tested are justified. The agglutination titres with ethanol-treated suspensions are more or less uniformly low.

Brutsaert (1924) investigated the serological relationships between $O$ and $\mathbf{H}$ antigens in this group, using mainly one strain, on lines similar to those followed generally in working with $\mathbf{H}$ and $\mathbf{O}$ antigens in the Salmonella group. His 'complete $\mathrm{H}$ and $\mathrm{O}$ antigens' was a suspension heated $1 \mathrm{hr}$. at $56^{\circ}$, and his $\mathrm{O}$ antigen a suspension boiled for $2 \mathrm{hr}$. Antisera prepared with the first suspension agglutinated only ' $\mathbf{H}+\mathbf{O}$ ' suspensions; the serum prepared with the boiled suspension agglutinated both kinds of suspension, as did also a serum prepared with a boiled $\mathbf{O}$-variant of another pyocyanea strain.

\section{Experimental}

Strains growing in blue-green colonies with iridescent spots, and matt yellow strains, thus widely different in their cultural characteristics, were selected on the assumption they would differ also in antigenic structure. The first two sera were accordingly prepared against a blue iridescent and a matt yellow strain respectively. The sera, however, gave strong cross-reactions, and agglutinated 60 strains of $P s$. pyocyanea to approximately the same titre. With crossabsorption tests only minor differences in the antigenic structure of the two strains were found. Other sera were prepared with strains not agglutinated by these sera, until finally five sera were available, one of them, no. IV, being prepared against a non-motile strain for serological analysis of the organism.

All these sera were prepared by injecting rabbits 5-6 times at weekly intervals with suspensions heated for $\frac{1}{2} \mathrm{hr}$. at $60^{\circ}$, the doses rising from 20 to 1000 million organisms. The strains tested were from different sources, most of them from human material like pus (from various sites), sputum, faeces, cervix uteri, and cerebrospinal fluid; very few came from water. Those which did not grow at $37^{\circ}$ were excluded on the grounds that they were unlikely to be true $P s$. pyocyanea. The agglutinations were carried out with the unheated living suspensions, first at $37^{\circ}$ for $2-4 \mathrm{hr}$., then at room temperature overnight. The agglutination was $\mathrm{O}$ in type.

In Table 1 the patterns of agglutination and the number of strains producing them are set out. It would appear that there are three main antigens, A, B and $\mathrm{C}$, for which the corresponding antibodies are contained in sera II, IV 
and $V$ respectively; and that all the possible patterns of agglutination depend, generally speaking, on the presence or absence or else the difference in quantity of these three antigens. The 54 strains may be grouped as follows.

\begin{tabular}{|c|c|c|c|}
\hline Mainly A & ntigen & \multicolumn{2}{|c|}{28 strains } \\
\hline $\mathbf{A}+\mathbf{B}$ & ," & 8 & $"$ \\
\hline B & , & 4 & , \\
\hline $\mathrm{C}$ & ," & 5 & , \\
\hline$B+C$ & ", & 1 & , \\
\hline Small amount & of one or the other antigen & 6 & , \\
\hline Not agglutina & & 2 & , \\
\hline
\end{tabular}

It is possible that the five strains which agglutinate only to low titre with sera I and IV have another main antigen in common, which may be present also in those two $B$ strains which agglutinated to a low titre with serum $I$.

Table 1. Serological relations of 54 strains of Pseudomonas pyocyanea

$\overbrace{\begin{array}{c}\text { Predominant } \\ \text { serological type }\end{array} \quad \begin{array}{c}\text { No. of } \\ \text { strains }\end{array}}^{\begin{array}{c}\text { suspensions of living } \\ \text { organisms tested }\end{array}}$

$\mathbf{A}$

A and $B$
C
$B$

$B$ and $C$

Miscellaneous

\begin{tabular}{|c|c|c|c|c|}
\hline \multicolumn{5}{|c|}{ Sera and predominating antibody } \\
\hline I & II & III & IV & $\mathbf{v}$ \\
\hline $\mathbf{A}$ & $\mathbf{A}$ & $A+B$ & B & C \\
\hline
\end{tabular}

Observed agglutination

$\begin{array}{ccccc}+++ & +++ & +++ & - & - \\ +++ & +++ & +++ & \pm & - \\ +++ & +++ & +++ & + & - \\ +++ & +++ & +++ & - & + \\ +++ & +++ & +++ & \pm & + \\ +++ & +++ & +++ & ++ & - \\ +++ & ++ & +++ & +++ & \pm \\ + & - & - & + & +++ \\ + & - & + & ++ & - \\ - & - & ++ & +++ & \pm \\ - & - & + & +++ & ++ \\ + & \pm & \pm & - & - \\ + & - & - & \pm & - \\ + & - & - & + & - \\ + & - & - & \pm & \pm \\ \pm & - & - & + & + \\ - & - & - & - & \pm\end{array}$

$\pm=$ partial agglutination to $1 / 160$.

,+++ and $t++=$ complete or almost complete agglutination to $1 / 160,1 / 640$ and $1 / 1280$ or more, respectively.

Numerous absorption experiments were carried out between the groups A. $A+B$ and $B$. They did not bring any new facts to light, but confirmed only the conclusions drawn on the basis of direct agglutinations. Serum III contains predominantly A-antibodies and only a small quantity of B-antibodies; the strain, however, with which it was prepared was agglutinated to titre by an anti-B serum, and absorption of serum III with an A strain left the B agglutinins unaffected. Some absorption experiments carried out within group A and within group B showed that within the group the strains were not com- 
pletely identical; minor differences were present. Each group contained blue as well as yellow strains excepting group $B$ in which all were yellow. Of the 54 strains three were non-motile; two in group B, and one, a blue strain, contained only small amounts of all three antigens.

In the above analysis there is no distinction of somatic and flagellar antigens. By analogy with the heat-labile flagellar antigens of the Salmonella and Proteus genera, antisera were prepared against bacterial suspensions heated in a boiling water bath for $2 \mathrm{hr}$. The strains were the same as those used to prepare sera I and II, namely $\mathbf{P} 8$ and 1602. Agglutination tests were made with living suspensions.

The antiserum to boiled P8 had lower titres throughout as compared with those of corresponding serum I; with some strains the drop was considerably greater than with others. The titres with the antiserum to boiled 1602 were identical with those of the corresponding serum II. The results of these experiments suggest that there is no more than a quantitative difference between the antisera obtained with the two differently treated suspensions.

An attempt to make a serum rich in flagellar antibodies was made by the method of Gohar (1932) for the preparation of Vibrio cholerae $\mathbf{H}$ antisera. A bacterial suspension of strain 'Molyneux' was shaken to tear the flagella off and centrifuged at moderate speed. The supernatant fluid, supposed rich in flagella, was then added to a bacterial suspension containing the full antigen, and the mixture used for immunization. A very high titre was obtained, but this serum again showed much the same range as the corresponding serum III. The appearance of the agglutination was definitely of the granular $\mathbf{O}$ type in both sera. Both serum III and the corresponding III flagellar serum were. absorbed with suspensions of normal organisms, of ethanol-treated organisms or of organisms grown on phenol agar. But the results were never quite clearcut enough to warrant drawing definite conclusions.

Having thus failed to obtain any conclusive evidence for the presence of distinct $\mathbf{O}$ and $\mathbf{H}$ antigens by this method, sera prepared against the whole untreated organism were tested against bacterial suspensions treated so as to serve as indicators for $\mathbf{H}$ and $\mathbf{O}$ agglutinins.

The usual procedure was adopted of treating bacterial suspensions with formalin for the preservation of $\mathrm{H}$ antigens in bacterial suspensions, and either with ethanol or heat at $100^{\circ}$ to obtain $O$ suspensions. Sixteen strains were chosen; three predominantly $A$, seven predominantly $A+B$, two predominantly $\mathbf{B}$, one $\mathbf{C}$, one $\mathbf{B}+\mathbf{C}$ and two strains which did not show any appreciable agglutination with any of the type sera, but which might manifest masked antigens as a result of the treatment. Sera I, II, III, IV, V and III flagellar were tested (Table 2).

The agglutinations with the formalin-treated suspensions were straight forward enough. In serum II, the purest A-serum available, the formalinized A strains were agglutinated to titre, but the $\mathbf{A}+\mathbf{B}$ strains had lost a good deal of their agglutinability. In serum I, also an A-serum, only two of the three A strains were clearly agglutinated. The third, and the $A+B$ strains, showed an appreciable loss of agglutinability. Serum III and serum III flagellar 
The serology of Ps. pyocyanea

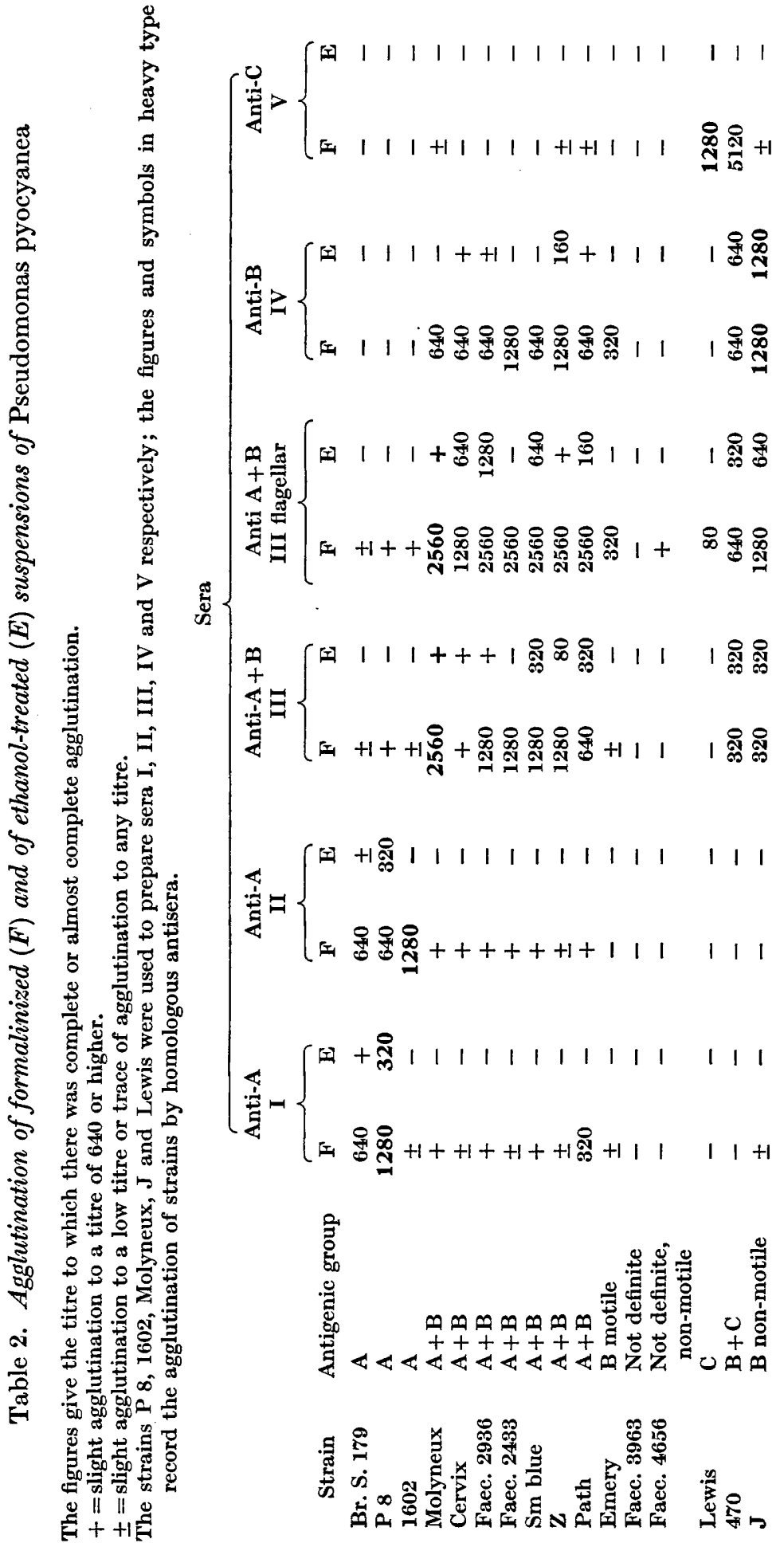


agglutinated the $\mathbf{A}+\mathbf{B}$ strains, $\mathbf{B}+\mathbf{C}$ strain and one of the $\mathbf{B}$ strains, the other B strain showed only traces of agglutination by serum III, but a clear-cut reaction with serum III flagellar; the agglutination of formalinized A strains was markedly diminished. The $\mathrm{B}$ serum and $\mathrm{C}$ serum agglutinated the formalinized suspensions to the same range and titre as the living suspensions.

The agglutination of formalinized suspensions only confirmed the grouping arrived at by the agglutination reactions with living organisms. Antigen $\mathbf{A}$ was affected by the formalin treatment to a considerable degree. By analogy with the Salmonellae, the B antigen, the main somatic antigen of two nonmotile strains, should have been affected at least to the same degree.

The agglutination of formalinized flagellated organisms by a serum like IV which contains probably only antibodies against somatic antigens would not occur in peritrichously flagellated organisms like those of the Salmonella group. That such an agglutination takes place with formalinized $P$ s. pyocyanea strains suggests that the antigenic modification by formalin of organisms with one terminal flagellum is not analogous with that of the Salmonellae.

In the preparation of ethanol suspensions it was found that suspensions kept in $30 \%(\mathrm{v} / \mathrm{v})$ ethanol-water lost their agglutinability within 2 days. Suspensions were therefore prepared by holding the bacteria in absolute ethanol at $45^{\circ}$ for $1 \mathrm{hr}$., at room temperature for $2 \mathrm{hr}$., then centrifuging and resuspending them in saline. Various attempts were made to grow the organisms for these suspensions on phenol agar to diminish flagellation, but even very small amounts of phenol decreased the yield largely and the concentration of phenol finally adopted, 1:2000, affected neither the growth nor the motility of the bacteria.

Agglutinations with ethanol-treated suspensions gave very much the same result as those with formalinized suspensions. The titre was lowered; and a few strains had lost their agglutinability altogether. For instance, the strain used to prepare serum II was not agglutinated by its own serum though strain I still was. One of the B strains was similarly inagglutinable. Strain 2433, an A + B strain, also lost its agglutinability after ethanol treatment, whereas in formalinized suspension it was agglutinated to titre by serum IV, prepared with a non-motile B strain. As already mentioned, the formalinized suspensions of all $A+B$ strains were agglutinated to titre by an anti-B serum, though from an orthodox viewpoint one might expect only the flagella in these formalinized suspensions to be reactive and no antibodies for them to be present in the B serum. Serum $\mathrm{V}$, a pure $\mathrm{C}$ serum, while agglutinating the $\mathrm{C}$ strain and the $\mathrm{B}+\mathrm{C}$ strain in formalinized suspensions, did not affect the ethanol-treated suspensions. Serum III, prepared with an A+B strain, agglutinated the ethanol suspensions of one strain $B$, and the $B+C$ strain to titre, but its agglutination with $\mathbf{A}+\mathrm{B}$ strains was much reduced. The $\mathbf{A}$ antigen, which had seemed to suffer most from formalin treatment, showed a still heavier loss in ethanol suspensions. There was not one instance in which the ethanol treatment had preserved an agglutinability which the formalin had destroyed.

Tests with heated suspensions were made, but had to be abandoned in view 
of the discovery that suspensions of $P s$. pyocyanea lost their agglutinability completely after heating. This loss occurred in suspensions heated $2 \mathrm{hr}$. in a boiling water bath, but was just as complete in suspensions heated for $\frac{1}{2} \mathrm{hr}$. at $60^{\circ}$ and was quite marked in suspensions heated for $\frac{1}{2} \mathrm{hr}$. at $53^{\circ}$. This is the more remarkable since all the sera had been prepared with suspensions heated at $60^{\circ}$ for half an hour. This is to say, with suspensions not themselves agglutinable it had been possible to produce sera of very high titre.

\section{DISCUSSION}

The experimental results described provide evidence for the existence in the species Ps. pyocyanea of three or possibly four main antigens. These antigens occur alone or in various combinations. It has not been possible to assign these antigens to definite parts of the bacterial surface, body or flagella. The reason for this failure is probably as follows. Of the usual methods for preparing $\mathbf{O}$ agglutinated suspensions heating must be excluded, as it makes the organisms inagglutinable, though they are still antigenic. A somewhat similar phenomenon has been described by Bawden \& Kleczkowski (1941, 1942), who found that certain antigens, when heated in the presence of other proteins, could no longer be precipitated by anti-serum though they were still antigenic; if heated alone, however, they retained their reactivity. The pyocyanea suspensions had been heated in pure salt solution, but it is possible that internal rearrangements in the chemically complex bacterial body produced combinations of antigenic and non-antigenic components such as Bawden \& Kleczkowski obtained by adding other proteins to their specific antigens. This phenomenon is being investigated further.

The ethanol treatment of organisms of this group appears to result in an impairment of the agglutinability, greater in degree than that caused by formalin treatment, but not differing from it in the distribution amongst various strains, so as to allow distinguishing between flagellar and somatic antigens. Some ethanol-treated suspensions were no longer agglutinated even by the homologous antiserum; and some ethanol-treated suspensions of strains containing $\mathbf{B}$ antigen were no longer agglutinated by serum IV which, being prepared with a non-flagellated strain, probably contains mainly somatic antibodies. In formalinized suspensions, on the other hand, the flagellated organisms containing antigen $\mathrm{B}$ were still agglutinated to titre by an $\mathrm{O}$-serum against $\mathrm{B}$; this is to say, they behave like formalinized non-flagellated organisms.

The formalinization of a non-flagellated organism of any kind does not reduce its $\mathrm{O}$-agglutinability. It is only in flagellated organisms that the formalin-fixed flagella prevent access of antibodies to the surface of the bacterial body. This is understandable with organisms that are peritrichously flagellated. But it will not necessarily follow for an organism with monotrichate flagellation. Gaby seems to have been the first to test formalinized and ethanol-treated suspensions of monotrichate organisms and to assume that the results so obtained had the same significance as in Proteus and Salmonella. 
Balteanu (1926), who analysed the antigenic structure of the cholera vibrio, used only the thermolability of the $\mathbf{H}$ and thermostability of the $\mathrm{O}$ antigen to distinguish between the two; and so did Brutsaert in his attempt to distinguish $\mathbf{H}$ and $\mathrm{O}$ antigens in Ps. pyocyanea. Gaby's absorption experiments with formalinized cells are beautifully clear-cut, and there is no doubt that he has revealed definite serological differences between the variant types. The variants clearly have one antigen in common which he assumes to be somatic, and differ in another antigen which he assumes to be flagella. But in the light of the demonstration here that agglutinability may be markedly diminished by a short ethanol treatment, further details of his ethanol treatment of cell suspensions are needed. Furthermore, one would hesitate to assume that the somatic antigen is invariably preserved and the flagellar antigen destroyed by ethanol treatment.

With regard to the preparation of agglutinating antisera all attempts to prepare antisera with distinct $\mathrm{O}$ and $\mathrm{H}$ antibodies for organisms of this group have failed. Brutsaert showed that a serum prepared with an organism heated at $56^{\circ}$ agglutinates such a heated suspension, but not one held for $2 \mathrm{hr}$. at $100^{\circ}$. So far this would correspond with the present experience that a heated suspension becomes inagglutinable; but his report of agglutination of both suspensions by a serum prepared with boiled organisms is wholly at variance with my results, unless he was dealing with an exceptional strain.

The use of bacteriophages for exploring antigenic structure promises well in this group. Preliminary experiments show that two phages, isolated by using an $\mathbf{A}$ strain and a B strain respectively as indicators, almost completely corresponded with the serological grouping in their attack on the various strains. The A strains were attacked by the A phage, the B strains by the $\mathbf{B}$ phage, the $\mathbf{A}+\mathbf{B}$ strains by both; the $\mathbf{C}$ strains were attacked only by the A phage, the $\mathrm{B}+\mathrm{C}$ strain again by both phages. As a rule phage susceptibility depends on somatic antigens, though Sertic \& Boulgakov (1936) have described a typhoid phage whose action depends on the presence of a particular flagellar antigen.

My phage experiments strongly support the grouping arrived at by serological methods, and while they do not prove conclusively that all the antigens established in the above experiments are somatic antigens, they make it very probable.

The $\mathbf{H}$ antigens may be undetectable because they are small in amount compared with the somatic antigens or, more likely, because the type of flagellation and other peculiarities of the species make the methods used generally for the detection of $\mathbf{H}$ antigens entirely inadequate in Ps. pyocyanea. It is also possible that the flagellar antigen is not different from the somatic one, and that in antigenic structure the flagellum constitutes just a part of the surface of the bacterial body. This has not been demonstrated in any other micro-organism, but is not improbable. In this connexion Pijper's (1946) contention that the bacterial structures hitherto regarded as flagella are only deformations of the slimy surface layer of bacteria is clearly relevant. 
I wish to thank Dr K. E. Cooper for much valuable criticism and advice, Dr V. Sertic in Zagreb for the stimulating discussion by correspondence of the subject, and the many colleagues in Bristol, Leeds and Wakefield who have kindly supplied me with strains of Ps. pyocyanea. I am indebted to the Colston Research Fund for aid with expenses.

\section{REFERENCES}

AokI, K. (1926). Agglutinatorische Einteilung von Pyocyaneus-Bazillen, welche bei verschiedenen Menschenerkrankungen nachgewiesen wurden. $\mathrm{Zbl}$. Bakt. (1. Abt. Orig.), 98, 186.

Balteanu, I. (1926). The receptor structure of Vibrio cholerae (V. comma) with observations on variations in cholera and cholera-like organisms. J. Path. Bact. 29, 251.

Bawden, F. C. \& Kleczkowski, A. (1941). Some properties of complexes formed when antigens are heated in the presence of serologically unspecific proteins. Brit. J. exp. Path. 22, 208.

Bawden, F. C. \& KLECzKowski, A. (1942). The antigenicity of non-precipitating complexes. Brit. J. exp. Path. 23, 169.

Brutsaert, P. (1924). L'antigène des bacilles pyocyaniques. C.R. Soc. Biol., Paris, 90, 1290.

GaBy, W. L. (1946). A study of the dissociative behaviour of Pseudomonas aeruginosa. J. Bact. 51, 217.

Gessard, C. (1919). Diagnose pigmentaire du bacille pyocyanique. Ann. Inst. Pasteur, 33, 241.

Gessard, C. (1920). Technique d'identification des germes pyocyaniques. Ann. Inst. Pasteur, 34, 88.

Gohar, M. A. (1932). A serological study of $V$. cholerae and related vibrios. Brit. J. exp. Path. 13, 371.

Pisper, A. (1946). Shape and motility of bacteria. J. Path. Bact. 58, 325.

SANDIFORd, B. R. (1937). Observations on Pseudomonas pyocyanea. J. Path. Bact. 44, 567 .

Sertic, V. \& Boulgakov, N. A. (1936). Bactériophages spécifiques pour des variétés bactériennes flagellées. C.R. Soc. Biol., Paris, 123, 887.

Trommsdorff, R. (1916). Zur Kenntnis des Bacterium pyocyaneum und seiner Beziehungen zu den fluoreszierenden Bakterien. Zbl. Bakt. (1. Abt. Orig.), 78, 493.

(Received 9 July 1947) 